\section{Imidacloprid Insecticide Slows Development of Phony Peach and Plum Leaf Scald}

\author{
James D. Dutcher ${ }^{1}$, Gerard W. Krewer ${ }^{2}$, and \\ Benjamin G. Mullinix, Jr. ${ }^{3}$
}

AdDitional index words. Xylella fastidiosa, fruit crop protection, roguing, Admire insecticide, soil drench, sharpshooters, Prunus persica, Prunus salicinia

SuMMARY. Observations in controlled field experiments over 5 years indicated that imidacloprid, applied as a soil drench around the trunks of peach (Prunus persica), nectarine (P. persica var. nectarine) and japanese plum (P. salicinia) trees at planting and in the early spring and mid-summer for two subsequent seasons $(0.7 \mathrm{~g} /$ tree a.i.), slowed the development of symptoms of phony peach disease (PPD) and plum leaf scald (PLS) (Xylella fastidiosa) in the trees. After 3.5 years, the percentage of peach trees showing PPD symptoms was $8.5 \%$ for the imidacloprid-treated trees compared to $34.3 \%$ for untreated trees. After 4.5 years, the percentage of peach trees showing PPD symptoms was $13.1 \%$ in the treated trees and $71.4 \%$ in the untreated trees. After 3.5 years, nectarine trees in untreated and treated plots showed PPD symptoms in $8.3 \%$ and $0.9 \%$ of the trees, respectively. After 4.5 years, PPD symptoms in nectarine were found in $32.3 \%$ of the untreated trees and $\mathbf{8 . 5 \%}$ of the treated trees. Development of PLS disease in plum was also slowed by the trunk drench with imidacloprid in two japanese plum varieties. After 3.5 years, dieback was observed in $\mathbf{5 5 \%}$ of the twigs of untreated and $23 \%$ of the twigs of treated trees of 'Au Rosa' plum and $33 \%$ of the twigs of untreated and $12 \%$ of the twigs of treated trees of 'Santa Rosa' plum.

$\mathrm{P}$ hony peach disease (PPD) and plum leaf scald (PLS), caused by Xylella fastidiosa and transmitted by sharpshooters including Homalodisca coagulata, $H$. insolita, Oncometopia orbona, Graphalocephala versuta (Insecta: Homoptera: Cicidellidae), are pernicious diseases in peach and japanese plum orchards in the moderate chilling gulf coast region of the southeastern U.S. (Wells et al., 1983).

We thank Paulk Farms for providing the land and materials for planting the trees and for technical assistance in the management of the trees during the 5 years of the experiments. Thanks to Bayer Corp. for supplying funding and insecticide for the experiments and the Georgia Cooperative Extension Service of Irwin Co. for assistance in setting out and evaluating the treatments. Thanks to Robert M. McPherson and Joe Williamson of the University of Georgia for reviewing the manuscript.

${ }^{1}$ Professor; to whom reprint requests should be addressed: Department of Entomology, University of Georgia, College of Agricultural and Environmental Sciences, Coastal Plain Experiment Station, Rainwater Rd., P.O. Box 748, Tifton, GA 31793-0748; e-mail: dutcher@tifton.uga.edu

${ }^{2}$ Professor, Department of Horticulture, University of Georgia, Rural Development Center, College of Agricultural and Environmental Sciences, P.O. Box 1209, Tifton, GA 31793.

${ }^{3}$ Agricultural Research Statistician, Department of Computer and Statistical Services, University of Georgia, College of Agricultural and Environmental Sciences, Tifton Campus, Tifton, GA 31793.
Control of PPD has been achieved in middle and northern Georgia by early detection, removal of trees with symptoms in the orchard, and removal of wild plums ( $P$. americana) adjacent to the orchard. Roguing is less effective in southern Georgia where milder winters lead to more severe disease pressure. In this region, the disease has contributed to a reduced commercial orchard life of Prunus spp. to 10 years or less. PLS limits the life of japanese plum orchards to less than 5 years in this region. Attempts to control glassy winged sharpshooter $(H$. coagulata) and PPD with DDT and encapsulated methyl parathion were not successful (Evert, 1989). Only roguing of infected trees after symptoms appear has been successful (Hutchins, 1933,
Mizell et al., 2003). Imidacloprid is a systemic insecticide that has efficacy against many homopteran pests (Mullins, 1993) and slows the development of pierce's disease in grapes (Vitisspp.) (Krewer et al., 2002). Pierce's disease also is caused by $X$. fastidiosa and is transmitted by sharpshooters (Mizell et al. 2003). The objective of this study was to determine if a soil drench of imidacloprid near the tree trunk at planting and for five seasons would reduce or control disease symptoms caused by $X$. fastidiosa in peach, nectarine, and japanese plum trees.

\section{Materials and methods}

Peach, nectarine, and plum trees were planted in Mar. 1996 on a Tifton loamy sand in Irwin County, Ga. (lat. $31^{\circ} 36^{\prime} \mathrm{N}$, long. $83^{\circ} 15^{\prime} \mathrm{W}$ ). The experimental peach site was adjacent to an established muscadine grape ( $V$. rotundifolia) vineyard on the south, a PPD-infected nectarine orchard on the east, open field on the west, and woods on the north. The experimental nectarine site was adjacent to an established muscadine grape vineyard on the east, a PPD-infected nectarine orchard on the west, asian pears (Pyrus pyrifolia) on the south, and a woodlot on the north. The experimental plum site was adjacent to an established vineyard of muscadine grapes on the east and south, an open field on the west, and figs (Ficus carica) on the north. Tree spacing was the same for all three crops with $20 \mathrm{ft}$ between rows and $15 \mathrm{ft}$ between trees within a row. Georgia Cooperative Extension Service recommendations (Ferree et al., 1989) were followed for fertilization and weed control in all three crops. Data for the peach experiment were analyzed by nonparametric sign tests (Conover, 1980). Data for the nectarine and plum experiments were analyzed by Proc Mixed (SAS, 1988) to determine mean, variation, and least significant differences for mean comparisons of

\begin{tabular}{llll}
\hline $\begin{array}{l}\text { Units } \\
\text { To convert U.S. to SI, } \\
\text { multiply by }\end{array}$ & U.S. unit & SI unit & $\begin{array}{l}\text { To convert SI to U.S., } \\
\text { multiply by }\end{array}$ \\
\hline 0.4047 & acre(s) & ha & 2.4711 \\
0.3048 & ft & $\mathrm{m}$ & 3.2808 \\
3.7854 & gal & $\mathrm{L}$ & 0.2642 \\
9.3540 & gal/acre & $\mathrm{L} \cdot h a-1$ & 0.1069 \\
2.5400 & inch(es) & $\mathrm{cm}$ & 0.3937 \\
25.4000 & inch(es) & $\mathrm{mm}$ & 0.0394 \\
28.3495 & oz & $\mathrm{g}$ & 0.0353 \\
70.0532 & oz/acre & $\mathrm{g} \cdot \mathrm{ha}-1$ & 0.0143 \\
6.8948 & psi & $\mathrm{kPa}$ & 0.1450
\end{tabular}


response variables.

Experimental design in the peach orchard was a split plot with two treatments and six blocks. Each block was a separate row of a different variety. However, varieties were not replicated and the treatments were not randomized. The six varieties were 'Flordaking', 'Junegold', 'Juneprince', 'LaPecher', 'LaFestival', and 'LaFeliciana'. Each block was divided into two plots for untreated control and imidacloprid treated trees. There were 262 trees in each treatment plot. Experimental design in the nectarine orchard was a randomized complete block with two treatments - untreated control and imidacloprid treated-in five blocks with five untreated control trees and 46 imidacloprid treated trees in each block. The number of untreated nectarine trees was low to minimize the build up of PPD in the orchard. Experimental design in the japanese plum plot was a randomized complete block. The entire plot had 36 trees and 18 trees were assigned to each of two treatments-untreated control and imidacloprid treated-in two blocks. Each block had 18 trees with one row of six trees of 'Santa Rosa' planted between two rows of six trees of 'AU Rosa' with nine trees assigned to each treatment in each japanese plum block.

Spring and summer applications of imidacloprid (Admire, Bayer CropScience, Kansas City, Mo.) were made to treated trees in 1996, 1997, and 1998. Only spring applications were made in 1999 and 2000 . The trees were producing a significant amount of fruit in 1999 and 2000 and were sprayed with cover sprays of insecticide during the spring and summer of these years to prevent buildup of fruit pests in the orchard. Spring applications were made 14 Apr. 1996, 14 Mar. 1997, 6 Mar. 1998, 15 Mar. 1999, and 10 Mar. 2000. Summer applications were made 2 Aug. 1996, 1 Aug. 1997, and 7 Aug. 1998. The amount of Admire $2 \mathrm{~F}$ formulation used was 2.9 L.ha' ${ }^{-1}$ for each application. Imidacloprid was applied at the rate of $0.7 \mathrm{~g} /$ tree a.i. The insecticide was applied by drenching the soil and lower trunk of the vine with a hand gun at a line pressure of 20 psi. Spray volume was altered to compensate for tree growth and a spray volume of 1 $\mathrm{L} /$ tree was applied in 1996 and 1997 and $2 \mathrm{~L} /$ tree in 1998, 1999 and 2000. The concentration of the solution was changed so that the same amount of actual insecticide was applied to each tree in both spray volumes. The spray volume was increased because the tree roots were larger and more area had to be covered with the drench.

Insect vectors were monitored, collected, and identified each week during 1996, 1997, and 1998 from March to October on yellow sticky board $(1 \times 2$-ft piece of $1 / 4$-inch-thick plywood) traps covered on both sides with Tanglefoot Insect Trap Coating (Tanglefoot Co., Grand Rapids, Mich.). Six yellow sticky boards were placed inside and six traps were placed around the periphery of each of the three experimental plot. The coating was replaced every 4-6 weeks depending on the condition of the sticky surface.

PPD symptoms of reduced shoot growth, internode length, and flattened leaf morphology (Mizell et al., 2003) were used in cursory visual disease ratings in the spring and fall of each season beginning in Fall 1996. Symptoms first appeared in Fall 1999 and each peach and nectarine tree was rated visually for symptoms on 21 Oct. 1999 and 4 Aug. 2000. PLS symptoms were assessed once on 21 Oct. 1999 by measuring the trunk diameter and counting the number of twigs that were dead in a random sample of 10 twigs per tree taken from the periphery of each tree. Trunk diameter was measured directly with a caliper. Twig dieback was measured by flexing the twigs. Brittle twigs that broke when flexed were counted as dead. Twig dieback data were analysed as counts (number dead out of 10 twigs) for each tree. For each treatment, 60 twigs were sampled from six 'Santa Rosa' tree and 120 twigs were sampled from 12 'AU Rosa' trees. Results are reported as the percentage of the total sample with twig dieback in each treatment.

\section{Results and discussion}

The level of PPD and PLS was relatively high at the orchard with $34 \%$ to $71 \%$ of the peach, $8 \%$ to $32 \%$ of the nectarine, and $100 \%$ of the plum trees showing PPD or PLS symptoms 4-5 years after planting. Insect vector abundance was moderate to high and there was considerable year-to-year variation in trap catch. Detailed discussion of the trapping results for insect vector is published (Krewer et al., 2002). A cursory overview of results of particular interest to the research with Prunus spp. follows. The abundance of four species of adult sharpshooters in the plots during 1996, 1997, and 1998 was continuous throughout the warm season (mid-March to mid-October) (Krewer et al., 2002). Over all years, sharpshooter species in order of relative abundance were $H$. coagulata, H. insolita, Oncometopia orbona, Graphalocephala versuta. For example, H. insolita was the most abundant sharpshooter in 1996 and the least abundant in 1998. Trap catch usually was between zeo and five insects of any species per trap per day. However, during peak activity, trap catch ranged as high as 40 insects of any species per trap per day. The time of peak activity of insects varied between years and species. Generally, in all 3 years, the trap catch indicated that vectors were significantly more active from late May to early August, with peak trap catch in mid-July. However, in 1996, $H$. insolita had three peaks of equal abundance in early May, mid-July and early October.

Visual signs of PPD did not appear in the peach orchard until Oct. 1999, 3.5 years after the initial planting and treatments (Table 1). In the untreated control, $34.3 \%$ of the trees were phony while $8.5 \%$ of the imidacloprid-treated trees were phony. In Aug. 2000, 71.4\% of the untreated control trees were phony and $13.1 \%$ of the imidaclopridtreated trees were phony. Also in the Aug. 2000 evaluation, some trees could not be categorized as having signs of PPD ("phony") or being completely healthy ("non-phony") and were classified as "may be phony." These trees had foliage that was slightly greener than the "non-phony" trees and/or the limbs had internode growth rated normal or only slightly less than normal. Some caution needs to be taken in interpreting these results as treatments were not randomly assigned. The sign test indicates if one random variable in a pair tends to be larger than the other. Untreated control tended to have more "phony" trees and less "non-phony" trees and the same number of "may be phony" trees in both 1999 and 2000 (Table 1). Sign test only says two treatments tend to differ. Confidence intervals and the amount of difference between treatments cannot be inferred due to a lack of randomization of treatments in the orchard.

Visual signs of PPD appeared in 
the nectarine orchard in Oct. 1999 (Table 2 ) when $8.3 \%$ of the untreated control trees were phony and $0.9 \%$ of the imidacloprid trees were phony, not a significant difference [least significant difference (LSD) at $P<0.05$ ]. In Aug. $2000,32.3 \%$ of the untreated control trees were phony and $8.5 \%$ of the imidacloprid trees were phony, not a significant difference (LSD, $P<0.05$ ). A confounding factor in the nectarine experiment was the higher incidence of phony trees across treatments in replications near the northern edge of the trial adjacent to the established phony infected nectarine orchard. A larger proportion of the nectarine trees $(24.4 \%)$ were classified as "may be phony" than in the peach orchard. The percentage of "non-phony" trees in the untreated trees was significantly lower than the percentage in the imidacloprid-treated trees (LSD, $P<0.05$ ).

Imidacloprid-treated plum trees appeared to be healthier than untreated trees in 1998 although trunk diameter was not significantly different between treatments in 1999 (Table 3). Imidacloprid-treated trees and untreated control trees had similar signs of plum leaf scald in 2000. PLS development was slower in imidacloprid-treated trees than in the untreated trees for the first 4 years after planting, but by the fifth year all trees showed signs of disease. Imidacloprid, formulated as Provado 1.6F (Bayer CropScience) has a U.S. label for use on peaches, nectarines, and plums as a foliar spray for the control of green peach aphid (Myzus persicae), green june beetle (Cotinis nitida), japanese beetle (Popillia japonica), potato leafhopper (Empoasca fabae), rose chafer (Macrodactylus subspinosus), san jose scale (Quadraspidiotus perniciosus), tarnished plant bug (Lygus lineolaris), and white apple (Typhlocyba pomaria) and suppression of plum curculio (Conotrachelusnemuphar) and stink bugs (Pentatomidae) plus control of western cherry fruit fly (Rhagoletis indifferens) on plums. (Note: The insect names mentioned above are all approved common names. The corresponding scientific names and other taxomonic information are published (Entomological Society of America, 2004)). Under the label guidelines, the maximum amount of actual insecticide for Provado 1.6F is $405 \mathrm{~g} \cdot \mathrm{ha}^{-1}$ a.i. per year for peaches and nectarines and $707 \mathrm{~g} \cdot \mathrm{ha}^{-1}$ a.i. per year for plums. A low to moderate tree density for
Table 1. Effect of imidacloprid on the development of phony peach disease (PPD) in a southern Georgia peach orchard 3.5 and 4.5 years after planting and the initiation of treatments. Imidacloprid was applied in March and August of 1996, 1997, and 1998 and in March of 1999 and 2000 as a soil drench to the area around the stem base of each plant. Imidacloprid was formulated as Admire 2F (Bayer CropScience, Kansas City, Mo.) and was applied at $0.7 \mathrm{~g} /$ tree $\mathbf{0 . 0 2 5}$ $\mathrm{oz} /$ tree) a.i. per application in sufficient water $[1-2 \mathrm{~L}(0.26-0.53 \mathrm{gal})]$ to drench the soil.

\begin{tabular}{llccr}
\hline & & \multicolumn{2}{c}{ Proportion of trees in indicated category $(\%)^{\mathrm{z}}$} \\
\cline { 3 - 5 } Year & Treatment & "non-phony" & "may be phony" & "phony" \\
\hline \multirow{2}{*}{1999} & Untreated control & $65.7 \mathrm{~b}$ & $0.0 \mathrm{a}$ & $34.3 \mathrm{~b}$ \\
\multirow{2}{*}{2000} & Imidaclorpid-treated & $91.5 \mathrm{a}$ & $0.0 \mathrm{a}$ & $8.5 \mathrm{a}$ \\
& Untreated control & $23.8 \mathrm{~b}$ & $4.8 \mathrm{a}$ & $71.4 \mathrm{~b}$ \\
& Imidacloprid-treated & $83.7 \mathrm{a}$ & $3.1 \mathrm{a}$ & $13.1 \mathrm{a}$ \\
\hline
\end{tabular}

${ }^{2}$ Total number of trees was 524 in 1999 and 494 in 2000. Means in the same year and column followed by the same letter do not tend to be different ( $\operatorname{sign}$ test $P<0.05$ ). Treatments were not assigned randomly to plots and nonparametric sign tests were used to analyze the data. A significant sign test (Conover, 1980) indicates that one mean in a pair (untreated control vs. imidacloprid-treated) tends to be larger than the other. Pairs in the same year and category with a significant sign test have means followed by different letters. Plants classified as "non-phony" had no visible disease symptoms. Plants classified as "phony" clearly had disease symptoms of dark green foliage and limbs with shortened internodes. Plants classified as "may be phony" had foliage that was slightly greener than the "non-phony" trees and/or the limbs had internode growth rated normal or only slightly less than normal but could not be clearly classified as "non-phony" or "phony."

Table 2. Effect of imidacloprid on the development of phony peach disease (PPD) in a southern Georgia 'Snow Queen' nectarine orchard 3.5 and 4.5 years after the planting and initiation of treatments. Imidacloprid was applied as a soil trench to the area around the stem at planting and each year afterward in March and August of 1996, 1997, and 1998 and in March of 1999 and 2000. Imidacloprid was formulated as Admire 2F (Bayer CropScience, Kansas City, Mo.) and was applied at $0.7 \mathrm{~g} /$ tree $(0.025 \mathrm{oz} /$ tree $)$ a.i. per application in sufficient water [1-2 L (0.26-0.53 gal)] to drench the soil.

\begin{tabular}{llccr}
\hline & & \multicolumn{2}{c}{ Proportion of trees in indicated category $(\%)^{\mathrm{z}}$} \\
\cline { 3 - 5 } Year & Treatment & "non-phony" & "may be phony" & "phony" \\
\hline \multirow{2}{*}{1999} & Untreated control & $91.7 \mathrm{a}$ & $0.0 \mathrm{a}$ & $8.3 \mathrm{a}$ \\
\multirow{2}{*}{2000} & Imidacloprid-treated & $99.1 \mathrm{a}$ & $0.0 \mathrm{a}$ & $0.9 \mathrm{a}$ \\
& Untreated control & $49.2 \mathrm{~b}$ & $18.5 \mathrm{a}$ & $32.3 \mathrm{a}$ \\
& Imidacloprid-treated & $85.6 \mathrm{a}$ & $5.9 \mathrm{a}$ & $8.5 \mathrm{a}$ \\
\hline
\end{tabular}

${ }^{2}$ Least significant difference (LSD) $(P<0.05)$ for 1999 was $7.8 \%$; LSD $(P<0.05)$ for 2000 was 31.6\%. Total number of trees was 226 . Means in the same year and column followed by the same letter are not significantly different (LSD, $P<0.05)$. Plants classified as "non-phony" had no visible disease symptoms. Plants classified as "phony" clearly had disease symptoms of dark green foliage and limbs with shortened internodes. Plants classified as "may be phony" had foliage that was slightly greener than the "non-phony" trees and/or the limbs had internode growth rated normal or only slightly less than normal but could not be clearly classified as "non-phony" or "phony."

Table 3. Effect of imidacloprid on the development of plum leaf scald (PLS) in a southern Georgia plum orchard 3.5 years after (Fall 1999) the planting and the initiation of treatments as a soil drench to the area around the stem base of each plant. Treatments were applied applied in March and August of 1996, 1997, and 1998 and in March of 1999 and 2000. Imidacloprid was formulated as Admire 2F (Bayer CropScience, Kansas City, Mo.) and was applied at $0.7 \mathrm{~g} /$ tree $(0.025$ $\mathrm{oz} /$ tree $)$ a.i. per application in sufficient water $[1 \mathrm{~L}(0.26 \mathrm{gal})]$ to drench the soil.

\begin{tabular}{llcc}
\hline Variety & \multicolumn{1}{c}{ Treatment } & Trunk diameter $(\mathbf{m m})^{\mathrm{z}, \mathrm{y}}$ & Twig dieback (\%) \\
\hline AU Rosa & Untreated control & $68.8 \mathrm{a}$ & $55.0 \mathrm{a}$ \\
AU Rosa & Imidacloprid treated & $82.0 \mathrm{a}$ & $22.7 \mathrm{~b}$ \\
Santa Rosa & Untreated control & $71.5 \mathrm{a}$ & $32.5 \mathrm{a}$ \\
Santa Rosa & Imidacloprid treated & $85.0 \mathrm{a}$ & $11.8 \mathrm{~b}$ \\
LSD $(P<0.05)$ & & 20.4 & 15.4 \\
\hline
\end{tabular}

${ }^{2}$ Means in the same variety and column and followed by the same letter are not significantly different [least significant difference (LSD) at $P<0.05]$. Trunk diameter was measured directly with a caliper. Twig dieback is the percentage of the twigs sampled that were brittle and dead. For each treatment, 12 trunks and 120 twigs were sampled from 12 'Santa Rosa' tree and 24 trunks and 240 twigs were sampled from 24 'AU Rosa' trees.

$\mathrm{y} 1 \mathrm{~mm}=0.0394$ inch. 
peach orchards ranges from 300 to 450 trees/ha (Kamas et al., 1998; Rader et al., 1985). Admire 2F has a U.S. label for use on pecan (Carya illinoinensis), citrus (Citrus spp.) and many other crops, vines, and vegetables (Bayer CropScience) and is applied to the soil at 340 to $680 \mathrm{~g} \cdot \mathrm{ha}^{-1}$ a.i. per season. The rate that was applied in this experiment was $0.7 \mathrm{~g} /$ tree a.i or 210 to $315 \mathrm{~g} \cdot \mathrm{ha}^{-1}$ a.i. per application.

Further research is needed before the technique can be adopted by growers. Our results are applicable to orchards with low to moderate tree density. The effective rate of application needs to be determined for highdensity plants that can have as many as 2300 trees/ha (Miles et al., 1999). Our results indicate that the trunk drench application of imidacloprid has an effect on the rate of development of phony peach disease for the first 5 years after planting. Use of imidacloprid for reducing the rate of development of phony peach disease is the first time since roguing was introduced (Hutchins et al., 1933) that a treatment has shown any indication of reducing the severity of the disease. It may be possible to enhance the control of PPD and extend orchard life or the treatment may work in conjunction with other vector control techniques that have shown promise against pierce's disease, such as kaolin sprays (Puterka et al., 2003) or biological control (Lopez et al., 2004). Our results also indicate that use of imidacloprid was not as effective in reducing severity of PLS in plums as PPD in peach and nectarine.

\section{Literature cited}

Conover, W.J. 1980. Practical nonparametric statistics. 2nd ed. Wiley, New York.

Entomological Society of America. 2004. Common names of insects and related organisms. 8 Feb. 2005. <http://www. entsoc.org/Common/index.asp>.

Evert, D.R. 1989. Phony peach, p. 136-13. In: S.C. Myers (ed.). Peach production handbook. Univ. Georgia Coop. Ext. Serv. Hdbk. 1 .

Ferree, M.E. and S.C. Meyers. 1989. Nutrition, p. 61-69. In: S.C. Myers (ed.). Peach production handbook. Univ. Georgia Coop. Ext. Serv. Hdbk. 1.

Hutchins, L.M. 1933. Identification and control of the phony disease of the peach. Office of State Entomologist, State Capital, Atlanta, Ga. Bul. 78.

Kamas, J., G.R. McEachern, L. Stein, and N. Roe. 1998. Peach production in Texas. 8 Feb 2005. <http://aggie-horticulture.tamu.edu/extension/peach/peach. html>.

Krewer, G., J.D. Dutcher, and C.J. Chang. 2002. Imidacloprid insecticide slows development of pierce's disease in bunch grapes. J. Entomol. Sci. 37:101-112.

Lopez, R., R.F Mizell, P.C Andersen, and B.V. Brodbeck. 2004. Overwintering biology, food supplementation and parasitism of eggs of Homalodisca coagulata (Say) (Homoptera: Cicadellidae) by Gonatocerus ashmeadi Girault and Gonatocerus morrilli (Howard) (Hymenoptera: Mymaridae). J. Entomol. Sci. 39(2):214-222.
Miles, N.W., R. Guarnaccia, and K. Slingerland. 1999. High density peach production in Ontario. New York Fruit Quarterly 7(4):1-5.

Mizell, R.F., P.C. Anderson, C. Tipping, and B. Brodbeck. 2003. Xylella fastidiosa diseases and their leafhopper vectors. Univ. Florida Ext. Serv. ENY-683. 8 Feb. 2005. <http://edis.ifas.ufl.edu/pdffiles/IN/ IN17400.pdf $>$.

Mullins, J.W. 1993. Imidacloprid: A new nitroguanidine insecticide. ACS Symp. Ser., Amer. Chem Soc. 524:183-198.

Puterka, G.J., M. Reinke, D. Luvisi, M.A. Ciomperik, D. Bartels, L. Wendel, and D.M. Glenn. 2003. Particle film, Surround WP, effects on glassy-winged sharpshooter behavior and its utility as a barrier to sharpshooter infestations in grape. Plant Health Progress doi:10.1094/PHP-20030321-01-RS. 8 Feb. 2005. <http://www. plantmanagementnetwork.org/sub/php/ research $/ 2003 /$ gwss/>.

Rader, J.S., R.H. Walser, C.F. Williams, and T.D. Davis. 1985. Organic and conventional peach production and economics. Biolog. Agr. Hort. 2:215-222.

SAS Institute, Inc. 1988. SAS user's guide: statistics, vers. 6.03 ed. SAS Inst., Cary, N.C.

Wells, J.M., B.C. Raju, and G. Nyland. 1983. Isolation, culture and pathogenicity of the bacterium causing phony disease of peach. Phytopathology 73:859-862. 